Supporting Information for:

\title{
Structural Diversity in Copper-Sulfur Chemistry: Synthesis of Novel Cu/S Clusters through Metathesis Reactions
}

\author{
John T. York, Itsik Bar-Nahum and William B. Tolman*
}

Department of Chemistry and Center for Metals in Biocatalysis, University of Minnesota, Minneapolis, MN 55455 


\section{Experimental Section}

General Considerations. All solvents and reagents were obtained from commercial sources and used as received unless noted otherwise. The solvents tetrahydrofuran (THF), diethyl ether $\left(\mathrm{Et}_{2} \mathrm{O}\right)$, pentane, and dichloromethane $\left(\mathrm{CH}_{2} \mathrm{Cl}_{2}\right)$ were degassed and passed through a solvent purification system (Glass Contour, Laguna CA) before use. The NMR solvents $\mathrm{CD}_{2} \mathrm{Cl}_{2}$ and $\mathrm{C}_{6} \mathrm{D}_{6}$ were dried over $\mathrm{CaH}_{2}$ and degassed before use. All metal complexes were prepared and stored in a Vacuum Atmospheres inert atmosphere glove box under a dry nitrogen atmosphere or were manipulated using standard inert atmosphere vacuum and Schlenk techniques. The complexes $\mathrm{Cu}\left(\mathrm{CF}_{3} \mathrm{SO}_{3}\right)_{2}, \mathrm{CuCl}_{2}, \mathrm{Li}_{2} \mathrm{~S}$, and (1R,2R)-(+)-1,2-diaminocyclohexane L-tartrate were purchased from Aldrich chemicals and used as received. The ligand $\mathrm{Me}_{4} \mathrm{chd},{ }^{1}$ sodium disulfide $\left(\mathrm{Na}_{2} \mathrm{~S}_{2}\right),{ }^{2}$ and the copper(I) complex $\left[\mathrm{Cu}^{\mathrm{I}}(\mathrm{MeCN})_{4}\right] \mathrm{SbF}_{6}{ }^{3}$ were synthesized according to published procedures.

Physical Methods. NMR spectra were recorded on either a Varian VI-300 or VXR-300 spectrometer. Chemical shifts $(\delta)$ for ${ }^{1} \mathrm{H}(300 \mathrm{MHz})$ and ${ }^{13} \mathrm{C}(75 \mathrm{MHz}) \mathrm{NMR}$ spectra are reported versus tetramethylsilane and were referenced to residual nuclei in the deuterated solvent. Mass spectra were obtained on a Bruker Biotof II instrument. UV-vis spectra were recorded on an HP8453 (190-1100 nm) diode array spectrophotometer. Resonance Raman spectra were collected on an Acton AM-506 spectrometer using a Princeton Instruments LN/CCD-11100PB/UVAR detector and ST-1385 controller interfaced with Winspec software. A Spectra-Physics BeamLok 2060-Kr laser provided excitation at $568.2 \mathrm{~nm}$ and $647.1 \mathrm{~nm}$, and excitation at 457.9 $\mathrm{nm}$ was provided by a Spectra-Physics BeamLok 2065-7S Ar laser. The spectra were obtained at $-196{ }^{\circ} \mathrm{C}$ using a backscattering geometry. Samples were frozen in an NMR tube submerged in liquid $\mathrm{N}_{2}$. Raman shifts were externally referenced to liquid indene.

[( $\left.\left.\mathbf{M e}_{4} \mathbf{c h d}\right) \mathbf{C u}^{\mathbf{I}}(\mathbf{M e C N})\right] \mathbf{S b F}_{6} .55 \mathrm{mg}(0.32 \mathrm{mmol})$ of the ligand $\mathrm{Me}_{4}$ chd were added to a solution of $\left[\mathrm{Cu}^{\mathrm{I}}(\mathrm{MeCN})_{4}\right] \mathrm{SbF}_{6}(148 \mathrm{mg}, 0.32 \mathrm{mmol})$ in $10 \mathrm{~mL} \mathrm{CH}_{2} \mathrm{Cl}_{2}$. The solution was stirred for $30 \mathrm{~min}$, and the solvent volume was reduced to $\sim 3 \mathrm{~mL}$ under reduced pressure. Diethyl ether $(10 \mathrm{~mL})$ was added to the solution, resulting in the precipitation of a white solid. The solvent was decanted off, and the white solid was washed with diethyl ether $(3 \times 5 \mathrm{~mL})$ and dried under reduced pressure. Yield: $155 \mathrm{mg}(95 \%) .{ }^{1} \mathrm{H}$ NMR $\left(\mathrm{CD}_{2} \mathrm{Cl}_{2}\right): \delta 2.60(\mathrm{br} \mathrm{s}, 6 \mathrm{H}), 2.32-2.50$ (br m, $8 \mathrm{H}), 2.15(\mathrm{~s}, 3 \mathrm{H}), 1.94-2.02(\mathrm{~m}, 2 \mathrm{H}), 1.79-1.90$ (br m, 2H), 1.10-1.30 (br m, 4H). ${ }^{13} \mathrm{C} \mathrm{NMR}$ $\left(\mathrm{CD}_{2} \mathrm{Cl}_{2}\right): \delta 117.1,65.8,47.7,40.2,25.1,22.5,2.7$. ESI-MS: $\left[\left(\mathrm{Me}_{4} \mathrm{chd}\right) \mathrm{Cu}^{\mathrm{I}}(\mathrm{MeCN})\right]^{+}$calcd. $\mathrm{m} / z$ 274.1339, found 274.1313 .

$\left[\left(\mathrm{Me}_{4} \mathrm{chd}\right)_{3} \mathrm{Cu}_{3}(\mathbf{S})_{2}\right]\left(\mathrm{CF}_{3} \mathbf{S O}_{3}\right)_{3}(\mathbf{1}) .55 \mathrm{mg}(0.32 \mathrm{mmol})$ of the ligand $\mathrm{Me}_{4}$ chd were added to a suspension of $\mathrm{Cu}\left(\mathrm{CF}_{3} \mathrm{SO}_{3}\right)_{2}(117 \mathrm{mg}, 0.32 \mathrm{mmol})$ in $\mathrm{CH}_{2} \mathrm{Cl}_{2}(10 \mathrm{~mL})$, resulting in the formation of a blue solution over the course of $30 \mathrm{~min}$. The solution was filtered through a plug of Celite, and 3 equiv. of $\mathrm{Li}_{2} \mathrm{~S}$ ( $44 \mathrm{mg}, 0.96 \mathrm{mmol}$ ) were added to the solution, which rapidly became deep blue-green. The solution was stirred for $30 \mathrm{~min}$, filtered through Celite, and the solvent was removed under reduced pressure to yield a dark blue-green solid. Dark green crystals

\footnotetext{
${ }^{1}$ Mahadevan, V.; Zhiguo, H.; Cole, A. P.; Root, D. E.; Lal, T. K.; Solomon, E. I.; Stack, T. D. P. J. Am. Chem. Soc. 1997, 119, 11996.

${ }^{2}$ Takata, T.; Saeki, D.; Makita, Y.; Yamada, N.; Kihara, N. Inorg. Chem. 2003, 42, 3712.

${ }^{3}$ G. J. Kubas, Inorg. Synth. 1979, 19, 90.
} 
were grown by slow diffusion of pentane into a concentrated $\mathrm{CH}_{2} \mathrm{Cl}_{2}$ solution at $-20{ }^{\circ} \mathrm{C}$. Yield: $54 \mathrm{mg}$ (41\% based on $\mathrm{Cu}$ ). Anal. Calcd. for $\mathrm{C}_{33} \mathrm{H}_{66} \mathrm{Cu}_{3} \mathrm{~N}_{6} \mathrm{~S}_{5} \mathrm{O}_{9} \mathrm{~F}_{9}(1)$ : C, 32.68; H, 5.48; N, 6.93. Found: C, 32.71; H, 5.25; N, 6.68. Complex 1 was also obtained by addition of 1 equiv $\mathrm{Na}_{2} \mathrm{~S}_{2}$ to the 1:1 mixture of $\mathrm{Me}_{4}$ chd and $\mathrm{Cu}\left(\mathrm{CF}_{3} \mathrm{SO}_{3}\right)_{2}$ in $\mathrm{CH}_{2} \mathrm{Cl}_{2}$, and characterized by $\mathrm{X}$-ray crystallography and UV-vis spectroscopy. Yield: $52 \%$ based on $\mathrm{Cu}$.

[(Me $\left.\mathbf{4} \mathbf{c h d})_{4} \mathbf{C u}_{\mathbf{6}}\left(\mathbf{S}_{2}\right)_{\mathbf{4}} \mathbf{C l}_{\mathbf{4}}\right]$ (2). $100 \mathrm{mg}(0.59 \mathrm{mmol})$ of the ligand $\mathrm{Me}_{4}$ chd were added to a suspension of $\mathrm{CuCl}_{2}(80 \mathrm{mg}, 0.59 \mathrm{mmol})$ in $10 \mathrm{~mL} \mathrm{CH}_{2} \mathrm{Cl}_{2}$. The solution was stirred for $30 \mathrm{~min}$, during which time it became deep green. The solution was filtered through a plug of Celite and 4 equiv. of $\mathrm{Li}_{2} \mathrm{~S}$ (108 mg, $2.36 \mathrm{~mol}$ ) were added. The solution was stirred for $1 \mathrm{hr}$, during which time it became deep blue. The solution was filtered through a plug of Celite and the solvent was reduced to $\sim 3 \mathrm{~mL}$ under reduced pressure. A physical mixture of dark blue and colorless crystals were grown by slow diffusion of pentane at $-20{ }^{\circ} \mathrm{C}$ into the concentrated $\mathrm{CH}_{2} \mathrm{Cl}_{2}$ solution. Crude yield: $35 \mathrm{mg}$ ( $\sim 25 \%$ based on $\mathrm{Cu})$. Repeated attempts to obtain analytically pure material were unsuccessful due to the nature of the mixture obtained upon crystallization.

[( $\left.\left(\mathbf{M e}_{4} \mathbf{c h d}\right)_{2} \mathbf{C u}_{2}\left(\mathbf{S}_{2}\right)_{2} \mathbf{C l}_{2}\right]$ (3). $88 \mathrm{mg}(0.52 \mathrm{mmol})$ of the ligand $\mathrm{Me}_{4} \mathrm{chd}$ was added to 70 $\mathrm{mg}(0.52 \mathrm{mmol})$ of $\mathrm{CuCl}_{2}$ in $10 \mathrm{~mL}$ of $\mathrm{CH}_{2} \mathrm{Cl}_{2}$. The mixture was stirred for $30 \mathrm{~min}$, during which time it became deep green. The solution was filtered through a plug of Celite, and 2 equiv. of $\mathrm{Na}_{2} \mathrm{~S}_{2}(114 \mathrm{mg}, 1.03 \mathrm{mmol})$ were added. The solution was stirred for $2 \mathrm{~h}$, during which time it became deep blue. The solution was filtered through a plug of Celite to give a deep blue solution. A physical mixture of dark blue and colorless crystals were grown by slow diffusion of pentane into a concentrated $\mathrm{CH}_{2} \mathrm{Cl}_{2}$ solution at $-20{ }^{\circ} \mathrm{C}$. Crude yield: $55 \mathrm{mg}(\sim 32 \%$ based on $\mathrm{Cu})$. Repeated attempts to obtain analytically pure material were unsuccessful due to the nature of the mixture obtained upon crystallization.

$\left[\left(\mathbf{M e}_{4} \mathbf{c h d}\right)_{\mathbf{4}} \mathbf{C u}_{4}\left(\mathbf{S}_{2}\right)_{2} \mathbf{C l}_{2}\right]\left(\mathbf{S b F}_{6}\right)_{2}$ (4). $100 \mathrm{mg}(0.59 \mathrm{mmol})$ of the ligand $\mathrm{Me}_{4}$ chd were added to a suspension of $\mathrm{CuCl}_{2}(80 \mathrm{mg}, 0.59 \mathrm{mmol})$ in $10 \mathrm{~mL} \mathrm{CH}_{2} \mathrm{Cl}_{2}$. The solution was stirred for $30 \mathrm{~min}$, during which time it became deep green. The solution was filtered through a plug of Celite and 4 equiv. of $\mathrm{Li}_{2} \mathrm{~S}(108 \mathrm{mg}, 2.36 \mathrm{~mol})$ were added. The solution was stirred for $1 \mathrm{~h}$, during which time it became deep blue. The solution was filtered through a plug of Celite to give a deep blue solution, and 4 equiv. of $\left[\left(\mathrm{Me}_{4} \mathrm{chd}\right) \mathrm{Cu}^{\mathrm{I}}(\mathrm{MeCN})\right] \mathrm{SbF}_{6}(120 \mathrm{mg}, 2.4 \mathrm{mmol})$ were added. The solution turned from deep blue to deep green, and it was stirred for $30 \mathrm{~min}$. The solution was filtered through Celite, and the solvent was reduced to $\sim 3 \mathrm{~mL}$ under reduced pressure. A physical mixture of dark green and colorless crystals were grown by slow diffusion of pentane into the concentrated $\mathrm{CH}_{2} \mathrm{Cl}_{2}$ solution at $-20{ }^{\circ} \mathrm{C}$. Crude yield: $22 \mathrm{mg}$. Repeated attempts to obtain analytically pure material were unsuccessful due to the nature of the mixture obtained upon crystallization.

X-ray Crystallography. Crystal data and collection parameters are listed in Table S1. Crystals of appropriate size were chosen and placed in oil on the tip of a $0.1 \mathrm{~mm}$ diameter glass fiber and mounted on a Bruker or Siemens SMART Platform CCD diffractometer for data collection at 173(2) K. Data collections were carried out using MoKa radiation (graphite monochromator) with a detector distance of $4.9 \mathrm{~cm}$. A randomLy oriented region of reciprocal space was surveyed to the extent of one sphere and to a resolution of $0.84 \AA$. The intensity data 
were corrected for absorption and decay (SADABS) $)^{4}$. Final cell constants were calculated from a set of strong reflections from the actual data collection after integration (SAINT) ${ }^{5}$. The structures were solved by direct methods using SHELXL-97 ${ }^{6}$ or Sir-97 ${ }^{7}$ software. Full-matrix least squares/difference Fourier cycles were performed using SHELXL-97 ${ }^{6}$ software, which located the remaining non-hydrogen atoms. All non-hydrogen atoms were refined with anisotropic displacement parameters, unless otherwise noted in the detailed refinement descriptions below. All hydrogen atoms were placed in ideal positions and refined as riding atoms with relative isotropic displacement parameters. Space groups were determined based on systematic absences and intensity statistics. ${ }^{6}$ Pertinent details for each structure are noted below; see CIFs for full crystallographic information.

Table S1. Selected crystallographic information $\left(\mathrm{L}=\mathrm{Me}_{4} \mathrm{chd}\right)$.

\begin{tabular}{|c|c|c|c|}
\hline & {$\left[\mathrm{L}_{3} \mathrm{Cu}_{3} \mathrm{~S}_{2}\right]\left(\mathrm{CF}_{3} \mathrm{SO}_{3}\right)_{3} \cdot 2\left(\mathrm{CH}_{2} \mathrm{Cl}_{2}\right)$} & {$\left[\mathrm{L}_{4} \mathrm{Cu}_{6} \mathrm{Cl}_{4} \mathrm{~S}_{8}\right] \bullet 4\left(\mathrm{CH}_{2} \mathrm{Cl}_{2}\right)$} & {$\left[\mathrm{L}_{2} \mathrm{Cu}_{2} \mathrm{Cl}_{2} \mathrm{~S}_{4}\right] \cdot 2\left(\mathrm{CH}_{2} \mathrm{Cl}_{2}\right)$} \\
\hline formula & $\mathrm{C}_{35} \mathrm{H}_{70} \mathrm{Cl}_{4} \mathrm{Cu}_{3} \mathrm{~F}_{9} \mathrm{~N}_{6} \mathrm{O}_{9} \mathrm{~S}_{5}$ & $\mathrm{C}_{44} \mathrm{H}_{96} \mathrm{Cl}_{12} \mathrm{Cu}_{6} \mathrm{~N}_{8} \mathrm{~S}_{8}$ & $\mathrm{C}_{22} \mathrm{H}_{48} \mathrm{Cl}_{6} \mathrm{Cu}_{2} \mathrm{~N}_{4} \mathrm{~S}_{4}$ \\
\hline fw & 1382.69 & 1800.41 & 836.66 \\
\hline cryst syst & Monoclinic & Monoclinic & Monoclinic \\
\hline space group & $\mathrm{P} 2_{1}$ & $\mathrm{P} 2_{1}$ & $\mathrm{P} 2_{1}$ \\
\hline$a(\AA)$ & $15.6678(10)$ & $15.028(4)$ & $12.503(5)$ \\
\hline $\mathrm{b}(\AA)$ & $14.2575(9)$ & $15.526(4)$ & $12.391(5)$ \\
\hline c $(\AA)$ & $26.5917(16)$ & $16.968(4)$ & $13.243(8)$ \\
\hline$\alpha(\operatorname{deg})$ & 90 & 90 & 90 \\
\hline$\beta(\operatorname{deg})$ & $99.4270(10)$ & $114.692(4)$ & $118.000(6)$ \\
\hline$\gamma(\operatorname{deg})$ & 90 & 90 & 90 \\
\hline$V\left(\AA^{3}\right)$ & $5859.9(6)$ & $3597.2(15)$ & $1811.5(15)$ \\
\hline $\mathrm{Z}$ & 4 & 2 & 2 \\
\hline $\mathrm{T}(\mathrm{K})$ & $173(2)$ & $173(2)$ & $173(2)$ \\
\hline$\rho_{\text {calcd }}\left(\mathrm{Mg} / \mathrm{m}^{3}\right)$ & 1.567 & 1.662 & 1.534 \\
\hline$\theta$ range $(\mathrm{deg})$ & 0.78 to 25.04 & 1.32 to 25.06 & 1.74 to 25.04 \\
\hline$\mu\left(\mathrm{mm}^{-1}\right)$ & 1.518 & 2.457 & 1.868 \\
\hline reflcns collcd & 58071 & 36064 & 17932 \\
\hline unique reflcns & 20645 & 12699 & 6398 \\
\hline params & 1232 & 719 & 351 \\
\hline $\begin{array}{l}\mathrm{R} 1 \text {, wR2 (for } I \\
>2 \sigma(I))\end{array}$ & $0.0496,0.1122$ & $0.0282,0.0522$ & $0.0299,0.0667$ \\
\hline GOF & 1.027 & 1.001 & 1.013 \\
\hline $\begin{array}{l}\text { largest peak, } \\
\text { hole }\left(\text { e. } \AA^{3}\right)\end{array}$ & $0.958,-0.923$ & $0.441,-0.426$ & $0.520,-0.396$ \\
\hline
\end{tabular}

\footnotetext{
${ }^{4}$ An empirical correction for absorption anisotropy, R. Blessing, Acta Cryst. 1995, A51, 33.

${ }^{5}$ SAINT V6.45A, Bruker Analytical X-Ray Systems, Madison, WI (2001).

${ }^{6}$ SHELXTL V6.12, Bruker Analytical X-Ray Systems, Madison, WI (2000).

${ }^{7}$ Altomare, A.; Burla, M. C.; Camalli, M.; Cascarano, G. L.; Giacovazzo, C.; Guagliardi, A.; Moliterni, A. G. G.; Polidori, G.; Spagna, R. J. Appl. Cryst. 1999, 32, 115-119.
} 
Table S1 (cont).

\begin{tabular}{|c|c|c|}
\hline & {$\left[\mathrm{L}_{4} \mathrm{Cu}_{4} \mathrm{Cl}_{2} \mathrm{~S}_{4}\right]\left(\mathrm{SbF}_{6}\right)_{2} \cdot 3\left(\mathrm{CH}_{2} \mathrm{Cl}_{2}\right)$} & $\mathrm{LCuCl}$ \\
\hline formula & $\mathrm{C}_{43} \mathrm{H}_{94} \mathrm{Cl}_{8} \mathrm{Cu}_{4} \mathrm{~F}_{12} \mathrm{~N}_{8} \mathrm{~S}_{4} \mathrm{Sb}_{2}$ & $\mathrm{C}_{10} \mathrm{H}_{22} \mathrm{~N}_{2} \mathrm{CuCl}$ \\
\hline fw & 1860.76 & 269.29 \\
\hline cryst syst & Monoclinic & Orthorhombic \\
\hline space group & $\mathrm{P} 2_{1}$ & $\mathrm{P} 2{ }_{1} 2_{1} 2_{1}$ \\
\hline$a(\AA)$ & $8.7073(13)$ & $8.2309(10)$ \\
\hline $\mathrm{b}(\AA)$ & $21.205(3)$ & $10.8644(12)$ \\
\hline c $(\AA)$ & $19.464(3)$ & $14.0116(16)$ \\
\hline$\alpha(\operatorname{deg})$ & 90 & 90 \\
\hline$\beta(\operatorname{deg})$ & $92.307(3)$ & 90 \\
\hline$\gamma(\mathrm{deg})$ & 90 & 90 \\
\hline $\mathrm{V}\left(\AA^{3}\right)$ & $3590.8(9)$ & $1253.0(3)$ \\
\hline $\mathrm{Z}$ & 2 & 4 \\
\hline $\mathrm{T}(\mathrm{K})$ & $173(2)$ & $173(2)$ \\
\hline$\rho_{\text {calcd }}\left(\mathrm{Mg} / \mathrm{m}^{3}\right)$ & 1.721 & 1.428 \\
\hline$\theta$ range $(\mathrm{deg})$ & 1.05 to 25.07 & 2.37 to 24.98 \\
\hline$\mu\left(\mathrm{mm}^{-1}\right)$ & 2.386 & 1.924 \\
\hline reflens collcd & 30990 & 11052 \\
\hline unique reflcns & 12619 & 2231 \\
\hline params & 558 & 127 \\
\hline $\begin{array}{l}\mathrm{R} 1, w \mathrm{w} 2 \text { (for } I> \\
2 \sigma(I))\end{array}$ & $0.0613,0.1294$ & $0.0323,0.0562$ \\
\hline GOF & 1.075 & 1.005 \\
\hline $\begin{array}{l}\text { largest peak, hole (e. } \\
\left.\AA^{3}\right)\end{array}$ & $1.217,-1.083$ & $0.421,-0.646$ \\
\hline
\end{tabular}

$\left[\left(\mathrm{Me}_{4} \mathrm{chd}\right)_{3} \mathrm{Cu}_{3}\left(\mu-\mathrm{S}_{2}\right]\left(\mathrm{CF}_{3} \mathrm{SO}_{3}\right)_{3}\right.$ (1). Dark green block crystals suitable for X-ray crystallography were grown by slow diffusion of pentane into a concentrated $\mathrm{CH}_{2} \mathrm{Cl}_{2}$ solution at $-20{ }^{\circ} \mathrm{C}$. The space group chosen during XPREP was $\mathrm{P} 2{ }_{1}$, consistent with the known chirality of the $\mathrm{Me}_{4}$ chd ligand. Isotropic refinement in $\mathrm{P} 2{ }_{1}$ resulted in the location of all non-hydrogen atoms, which were subsequently refined anisotropically. Two independent $\left[\mathrm{L}_{3} \mathrm{Cu}_{3}(\mu-\mathrm{S})_{2}\right]^{3+}$ moieties are present in the asymmetric unit, along with three triflate anions per core and a total of four molecules of dichloromethane solvent. A pseudo-center of symmetry was detected by the ADDSYM function of PLATON, and the alternative space group $\mathrm{P} 2{ }_{1} / \mathrm{c}$ was suggested. This centrosymmetric space group is not consistent with the known chirality of the $\mathrm{Me}_{4}$ chd ligand, however, and refinement was completed in $\mathrm{P} 2{ }_{1}$. Due to the pseudo-symmetry present, the anisotropic displacement parameters of two of the triflate anions were strongly correlated, giving rise to unreasonable displacements. Refinement of the atoms related by the pseudo-symmetry with identical anisotropic displacement parameters (EADP constraints) resulted in reasonable displacements. In addition, the anisotropic displacement parameters of two molecules of dichloromethane solvent were also correlated by pseudo-symmetry, giving unreasonable displacements. Refinement of these atoms with EADP constraints did not improve the solution, however, and they were therefore refined independently. The final full-matrix least-squares converged to R1 $=0.0496$ (for $I>2 \sigma(I))$ and $w \mathrm{R} 2=0.1188\left(\mathrm{~F}^{2}\right.$, all data). 
[(Me 4 chd $\left.)_{4} \mathbf{C u}_{6}\left(\mathbf{S}_{2}\right)_{4} \mathbf{C l}_{4}\right]$ (2). A dark blue block crystal suitable for X-ray crystallography was selected from a physical mixture of dark blue and colorless crystals grown by slow diffusion of pentane into a concentrated $\mathrm{CH}_{2} \mathrm{Cl}_{2}$ reaction solution of $\mathrm{Me}_{4}$ chd, $\mathrm{CuCl}_{2}$, and $\mathrm{Li}_{2} \mathrm{~S}$ at $-20{ }^{\circ} \mathrm{C}$. The space group chosen during XPREP was $\mathrm{P} 2{ }_{1}$, consistent with the known chirality of the $\mathrm{Me}_{4}$ chd ligand. Isotropic refinement in this space group resulted in the location of all nonhydrogen atoms, which were subsequently refined anisotropically. Four molecules of dichloromethane solvent are present in the asymmetric unit. One molecule of dichloromethane was disordered and was refined over two positions with an occupancy factor of 73:27 for the two molecules. The final full-matrix least-squares refinement converged to R1 $=0.0282$ (for $I>$ $2 \sigma(I))$ and $\mathrm{wR} 2=0.0544\left(\mathrm{~F}^{2}\right.$, all data) .

[(Me $\left.\left.{ }_{4} \mathbf{c h d}\right)_{2} \mathbf{C u}_{2}\left(\mathbf{S}_{2}\right)_{2} \mathbf{C l}_{2}\right]$ (3). A dark blue crystal suitable for X-ray crystallography was selected from a mixture of dark blue and colorless crystals grown by slow diffusion of pentane into a concentrated $\mathrm{CH}_{2} \mathrm{Cl}_{2}$ reaction solution of $\mathrm{Me}_{4}$ chd, $\mathrm{CuCl}_{2}$, and $\mathrm{Na}_{2} \mathrm{~S}_{2}$ at $-20{ }^{\circ} \mathrm{C}$. The space group determined by XPREP was $\mathrm{P} 2{ }_{1}$, consistent with the known chiral nature of the $\mathrm{Me}_{4}$ chd ligand. Isotropic refinement in this space group resulted in the location of all non-hydrogen atoms, which were subsequently refined anisotropically. Two molecules of dichloromethane solvent were present with each molecule. The ADDSYM function of PLATON detected a pseudo-center of symmetry and suggested the use of the alternate space group $\mathrm{P} 2_{1} / \mathrm{c}$. The chiral nature of the $\mathrm{Me}_{4}$ chd ligand is not compatible with this space group, however, and refinement was completed in $\mathrm{P} 2_{1}$. The final final-full matrix least-squares refinement converged to $\mathrm{R} 1=$ 0.0299 (for $I>2 \sigma(I))$ and $\mathrm{wR} 2=0.0708\left(\mathrm{~F}^{2}\right.$, all data).

$\left[\left(\mathrm{Me}_{4} \mathbf{c h d}\right)_{4} \mathrm{Cu}_{4}\left(\mathbf{S}_{2}\right)_{2} \mathbf{C l}_{2}\right]\left(\mathrm{SbF}_{6}\right)_{2}$ (4). A dark green block crystal suitable for X-ray crystallography was selected from a physical mixture of green and colorless crystals grown by slow diffusion of pentane into a concentrated $\mathrm{CH}_{2} \mathrm{Cl}_{2}$ reaction solution of $\mathrm{Me}_{4}$ chd, $\mathrm{CuCl}_{2}, \mathrm{Li}_{2} \mathrm{~S}$, and $\left[\left(\mathrm{Me}_{4} \mathrm{chd}\right) \mathrm{Cu}^{\mathrm{l}}(\mathrm{MeCN})\right] \mathrm{SbF}_{6}$ at $-20{ }^{\circ} \mathrm{C}$. The space group originally determined by XPREP was $\mathrm{P} 2{ }_{1}$, which was consistent with the known chiral nature of the $\mathrm{Me}_{4}$ chd ligand. Isotropic refinement in $\mathrm{P} 2{ }_{1}$ resulted in the location of all non-hydrogen atoms. The ADDSYM function of PLATON detected a pseudo center of symmetry and suggested the use of the alternative space group $\mathrm{P} 2{ }_{1} / \mathrm{c}$. This centrosymmetic space group is not compatible with the known chiral nature of the $\mathrm{Me}_{4}$ chd ligand, and it was not used. Attempts to refine the structure anisotropically in $\mathrm{P} 2{ }_{1}$ failed, however, due to strong correlations in the anisotropic displacement parameters for atoms related by pseudo-symmetry. Examination of the systematic absence exceptions during XPREP revealed the presence of a pseudo $\mathrm{n}$-glide and $\mathrm{P} 2{ }_{1} / \mathrm{n}$ was listed as an option with the lowest CFOM (Figure of Merit). Isotropic refinement of the structure as a racemic mixture in $\mathrm{P} 2{ }_{1} / \mathrm{n}$ resulted in the location of all non-hydrogen atoms, and anisotropic refinement was also successful. The (1R,2R)-enantiomer was chosen, and the atomic coordinates and anisotropic displacement parameters for these atoms were converted into the space group $\mathrm{P} 2{ }_{1}$. Anisotropic refinement of the structure in $\mathrm{P} 2{ }_{1}$ using identical anisotropic displacement parameters (EADP constraints) for the atoms related by pseudo-symmetry resulted in convergence of the model. However, due to the strong pseudo-symmetry present and the correlations in the anisotropic displacement parameters, several atoms in the structure have large thermal ellipsoids which could not be improved. In addition to the main $\left[\mathrm{L}_{4} \mathrm{Cu}_{4}\left(\mathrm{~S}_{2}\right)_{2} \mathrm{Cl}_{2}\right]^{2+}$ cluster and two $\mathrm{SbF}_{6}$ anions present in the structure, three dichloromethane molecules are present. Two of these are related by pseudo-symmetry, and their anisotropic displacement parameters were refined with EADP 
constraints. The third molecule of dichloromethane was disordered over two positions related by pseudo-symmetry. This solvent molecule was refined as disordered over two positions in 50:50 occupancies. Attempts to model these atoms anisotropically gave unreasonable displacements, even with EADP constraints, and they were finally refined isotropically. The final full-matrix least-squares refinement converged to $\mathrm{R} 1=0.0613$ (for $I>2 \sigma(I)$ ) and $\mathrm{wR} 2=0.1382$ ( $\mathrm{F}^{2}$, all data).

( $\mathbf{M e}_{4}$ chd) CuCl. A colorless crystal suitable for X-ray crystallography was selected from a physical mixture of blue and colorless crystals grown by slow diffusion of pentane into a concentrated $\mathrm{CH}_{2} \mathrm{Cl}_{2}$ reaction solution of $\mathrm{Me}_{4} \mathrm{chd}, \mathrm{CuCl}_{2}$, and $\mathrm{Li}_{2} \mathrm{~S}$ at $-20{ }^{\circ} \mathrm{C}$. Several space groups were suggested by XPREP, with the achiral space group P $2{ }_{1} 2_{1} 2_{1}$ being the most consistent with the chiral nature of the $\mathrm{Me}_{4}$ chd ligand and the observed systematic absence statistics which indicated the presence of three screw axes. Isotropic refinement in P $2{ }_{1} 2_{1} 2_{1}$ resulted in the location of all non-hydrogen atoms, which were subsequently refined anisotropically. A pseudo-center of symmetry was detected by the ADDSYM function of PLATON, and the alternative space group $\mathrm{P}_{\mathrm{nma}}$ was suggested. This centrosymmetric space group is not compatible with the known chirality of the ligand, however, and structural refinement was completed in $\mathrm{P} 2{ }_{1} 2_{1} 2_{1}$. The final full-matrix least-squares refinement converged to $\mathrm{R} 1=0.0323$ (for $I>2 \sigma(I))$ and $\mathrm{wR} 2=0.0608\left(\mathrm{~F}^{2}\right.$, all data).

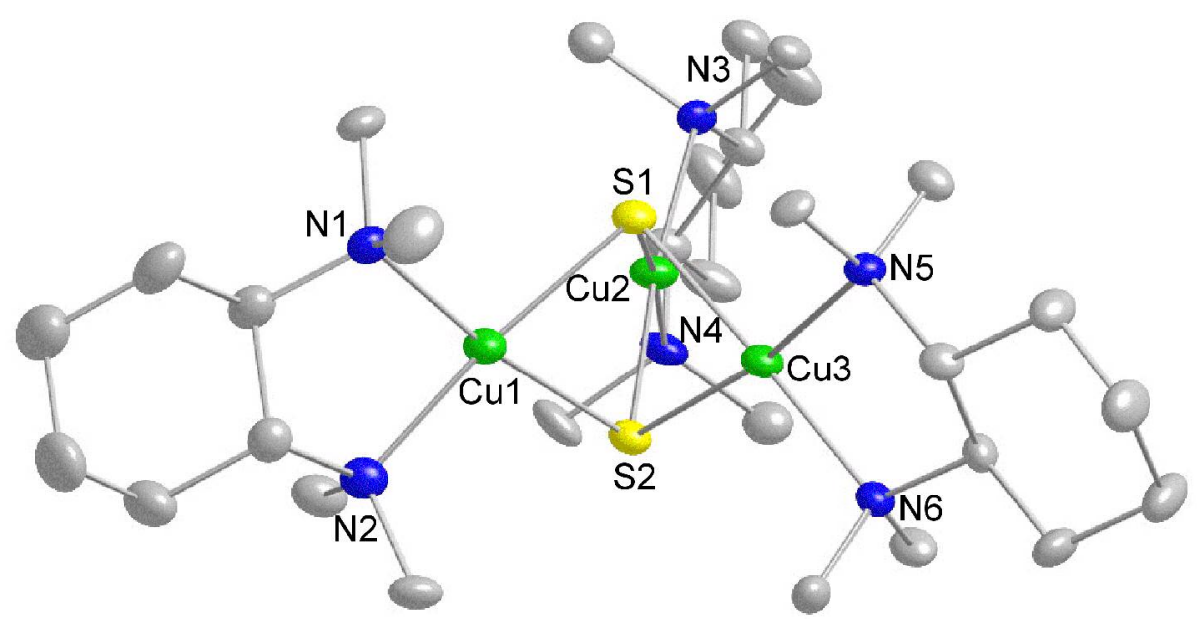

Figure S1. Molecular structure of the cationic portion of 1. (50\% thermal ellipsoids, H-atoms omitted for clarity). Only one of the two independent $\left[\mathrm{L}_{3} \mathrm{Cu}_{3}(\mu-\mathrm{S})_{2}\right]^{3+}$ cores is shown. Selected bond lengths (A): Cu1-S1, 2.246(2); Cu1-S2, 2.246(2); Cu2-S1, 2.2505(19); Cu2-S2, 2.2530(19); Cu3-S1, 2.248(2); Cu3-S2, 2.2550(19); Cu1-N1, 2.032(6); Cu1-N2, 2.042(6); Cu2N3, 2.028(5); Cu2-N4, 2.038(6); Cu3-N5, 2.038(5); Cu3-N6, 2.047(6). 


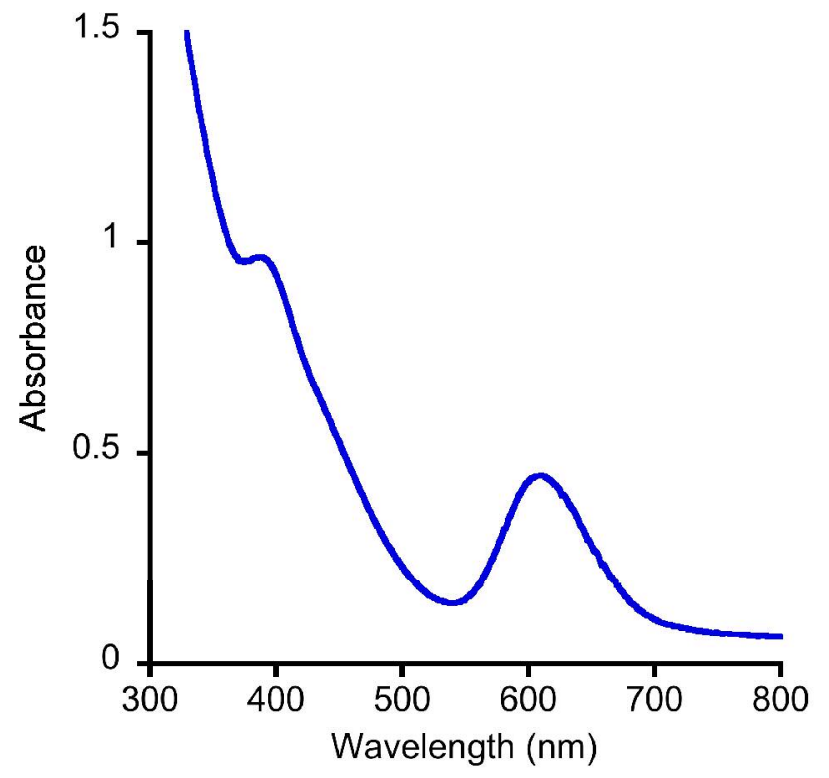

Figure S2. UV-vis spectrum of crude $\left[\left(\mathrm{Me}_{4} \mathrm{chd}\right)_{3} \mathrm{Cu}_{3}(\mu-\mathrm{S})_{2}\right]\left(\mathrm{CF}_{3} \mathrm{SO}_{3}\right)_{3}(\mathbf{1})$ in $\mathrm{CH}_{2} \mathrm{Cl}_{2}$ at $25^{\circ} \mathrm{C}$.

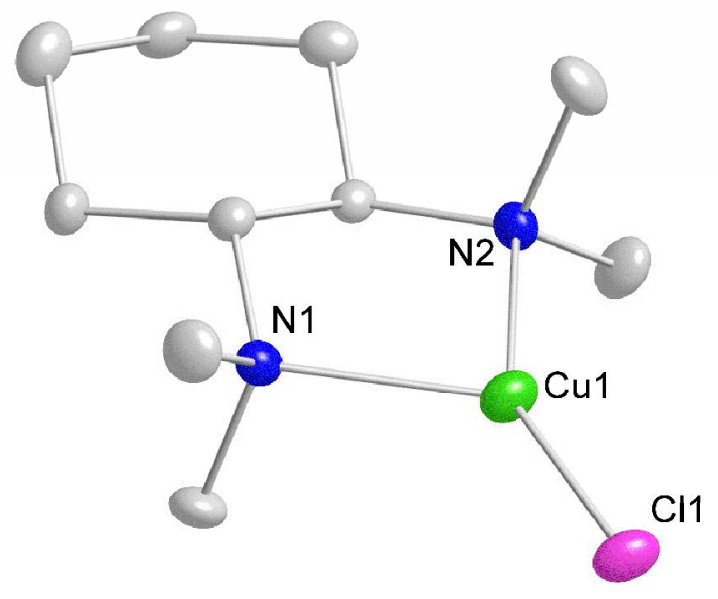

Figure S3. Molecular structure of $\left(\mathrm{Me}_{4} \mathrm{chd}\right) \mathrm{Cu}{ }^{\mathrm{I}} \mathrm{Cl}(50 \%$ thermal ellipsoids, $\mathrm{H}$-atoms omitted for clarity). Selected bond lengths (Å): Cu1-Cl1, 2.1254(8); Cu1-N1, 2.052(2); Cu1-N2, 2.151(3). 


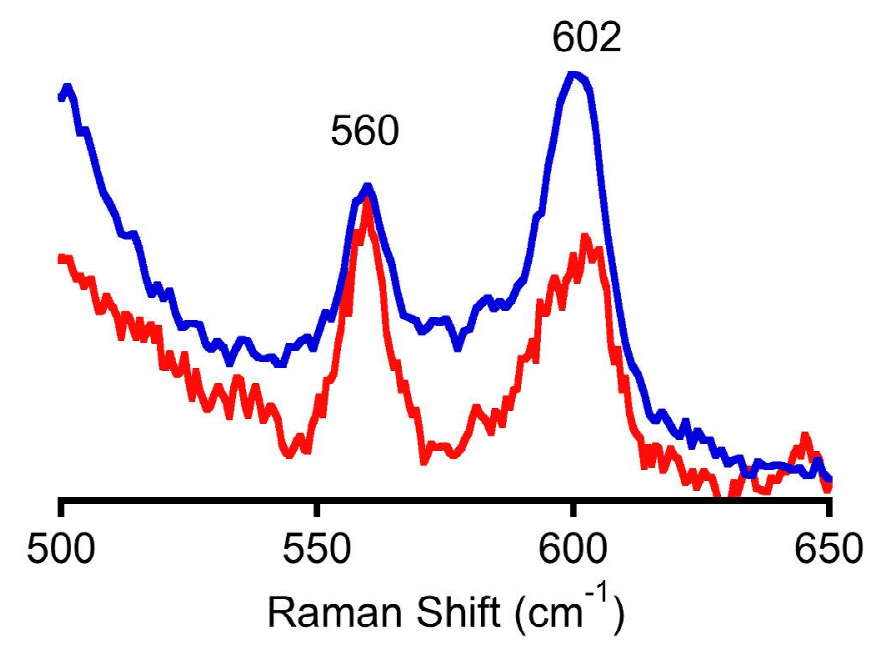

Figure S4. Resonance Raman spectra of the crude reaction mixtures of $\mathrm{L}, \mathrm{CuCl}_{2}$ and $\mathrm{Li}_{2} \mathrm{~S}$ (blue, $\left.\lambda_{\text {ex }}=457.9 \mathrm{~nm}, 77 \mathrm{~K}\right)$ and $\mathrm{Na}_{2} \mathrm{~S}_{2}\left(\mathrm{red}, \lambda_{\text {ex }}=568.2 \mathrm{~nm}, 77 \mathrm{~K}\right)$ in $\mathrm{CH}_{2} \mathrm{Cl}_{2}$.

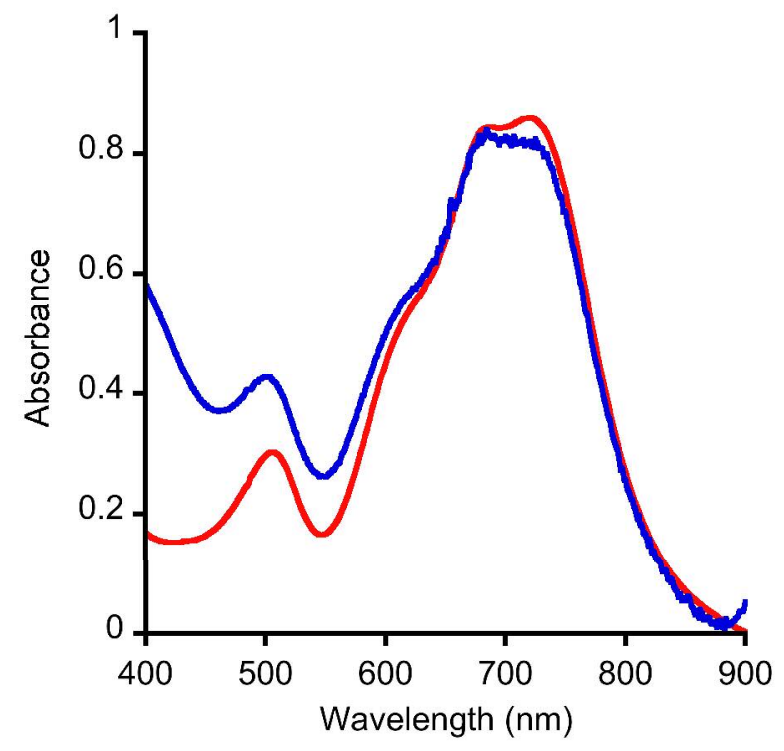

Figure S5. UV-vis spectra of re-dissolved crystals from the reactions of $\mathrm{L}, \mathrm{CuCl}_{2}$ and $\mathrm{Li}_{2} \mathrm{~S}$ (blue) and $\mathrm{Na}_{2} \mathrm{~S}_{2}$ (red) in $\mathrm{THF}$ at $25^{\circ} \mathrm{C}$. The absorbance scales are arbitrarily set so as to render the main absorption feature at ca. $700 \mathrm{~nm}$ similarly intense. 


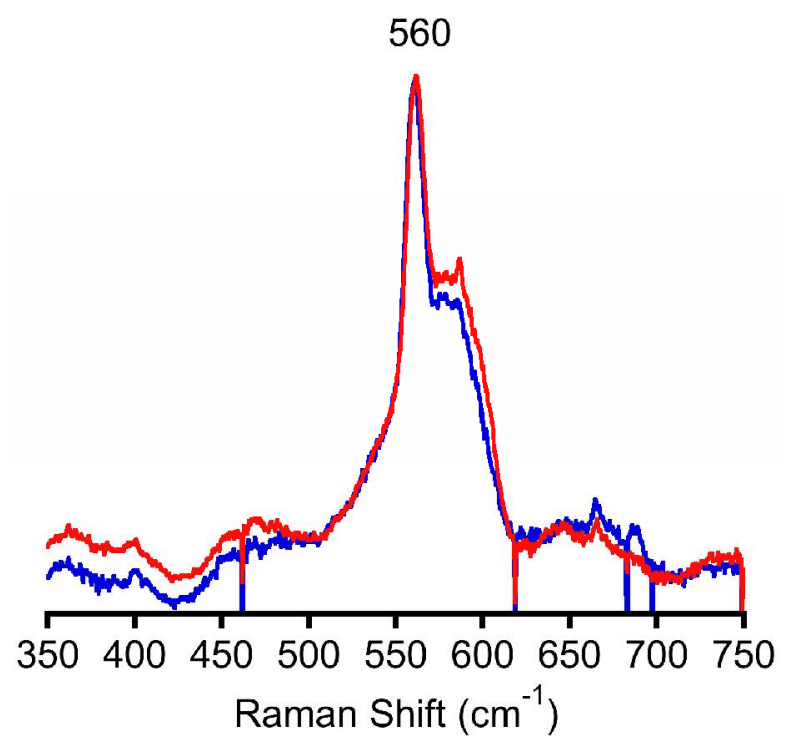

Figure S6. Resonance Raman spectra of re-dissolved crystals from the reactions of $\mathrm{L}, \mathrm{CuCl}_{2}$ and $\mathrm{Li}_{2} \mathrm{~S}$ (blue) and $\mathrm{Na}_{2} \mathrm{~S}_{2}$ (red) in THF $\left(\lambda_{\text {ex }}=647.1 \mathrm{~nm}, 77 \mathrm{~K}\right)$.

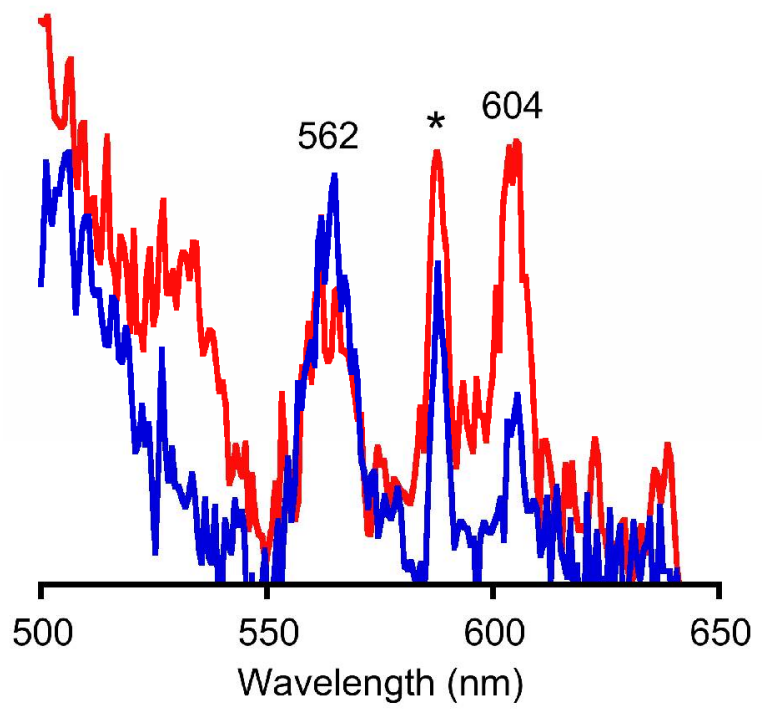

Figure S7. Resonance Raman spectra of re-dissolved crystals from the reactions of $\mathrm{L}, \mathrm{CuCl}_{2}$ and $\mathrm{Li}_{2} \mathrm{~S}$ (blue) and $\mathrm{Na}_{2} \mathrm{~S}_{2}$ (red) in THF $\left(\lambda_{\mathrm{ex}}=568.2 \mathrm{~nm}, 77 \mathrm{~K}, *\right.$ denotes solvent peak). 